\title{
NORMALLY MAGNETIZED LOWER TERTIARY LAVAS ON NÛGSSUAQ, CENTRAL WEST GREENLAND
}

\begin{abstract}
Niels Hald
Koch (1959) suggested that the basal pillow breccia of the volcanic sequence on southwestern Nûgssuaq around Nûk qiterdleq is equivalent to sediments from the Upper Atanikerdluk Formation deposited further east; and also that the tuff horizons found intercalated among the sediments in the Naujat Member of the Upper Atanikerdluk Formation and in the Abraham Member of the Upper Agatdal Formation are equivalent in time to these early breccias. Pedersen (1973) tentatively correlated interbasaltic bituminous shales found $1 \mathrm{~km}$ above the base of the volcanic sequence on northern Disko with sedimentary rocks of the Upper Atanikerdluk Formation and Upper Agatdal Formation on Nûgssuaq.

In agreement with these suggestions preliminary magnetic polarity measurements of basaltic lavas from Nûgssuaq indicate that the eruption of breccias and lavas started earlier in the outer Auvfarssuaq valley than in central and northern Nûgssuaq.

Eight profiles through the breccias and the lavas on Nugssuaq were measured during the field season of 1973: four along the north coast and four along the north side of the Auvfarssuaq valley (fig. 1). Rock specimens with the vertical direction marked were sampled with an interval of $30-50 \mathrm{~m}$. The magnetic polarity of the whole samples was measured in the laboratory. Selected specimens were cored parallel to the vertical direction; the polarity of the cores was determined on a spinner magnetometer before and after partial demagnetization in peak fields of 200-600 Oe.

The measurements have shown that the flat lying basaltic flows on Nûgssuaq east of the Itivdle valley are usually reversely magnetized like most of the Early Tertiary lavas in West Greenland (Kristjansson \& Deutsch, 1973, Athavale \& Sharma, 1975). An exception is profile 8 (fig. 1) on the north side of the Auvfarssuaq valley $14 \mathrm{~km}$ east of Marrait. Here more than $400 \mathrm{~m}$ of pillow breccias (base not exposed) are overlain by a $250 \mathrm{~m}$ thick sequence of normally magnetized lavas alternating with pillow breccias $(580-830 \mathrm{~m}$ above sea level). This sequence is followed by reversely magnetized lavas (fig. 2).

According to Athavale \& Sharma (1975) the lava pile on northern Disko, which is more than $3 \mathrm{~km}$ thick, is made up of a lower reversely magnetized section comprising only a few lava flows just above the pillow breccias; a middle section about $200 \mathrm{~m}$ thick of normally magnetized flows; and an upper section comprising the larger part of the pile consisting of reversely magnetized flows. It seems justified to correlate the normally magnetized lavas found in the outer part of the Auvfarssuaq valley on Nûgssuaq with the normally magnetized section on Disko and also with the normally magnetized lavas found by Athavale \&
\end{abstract}




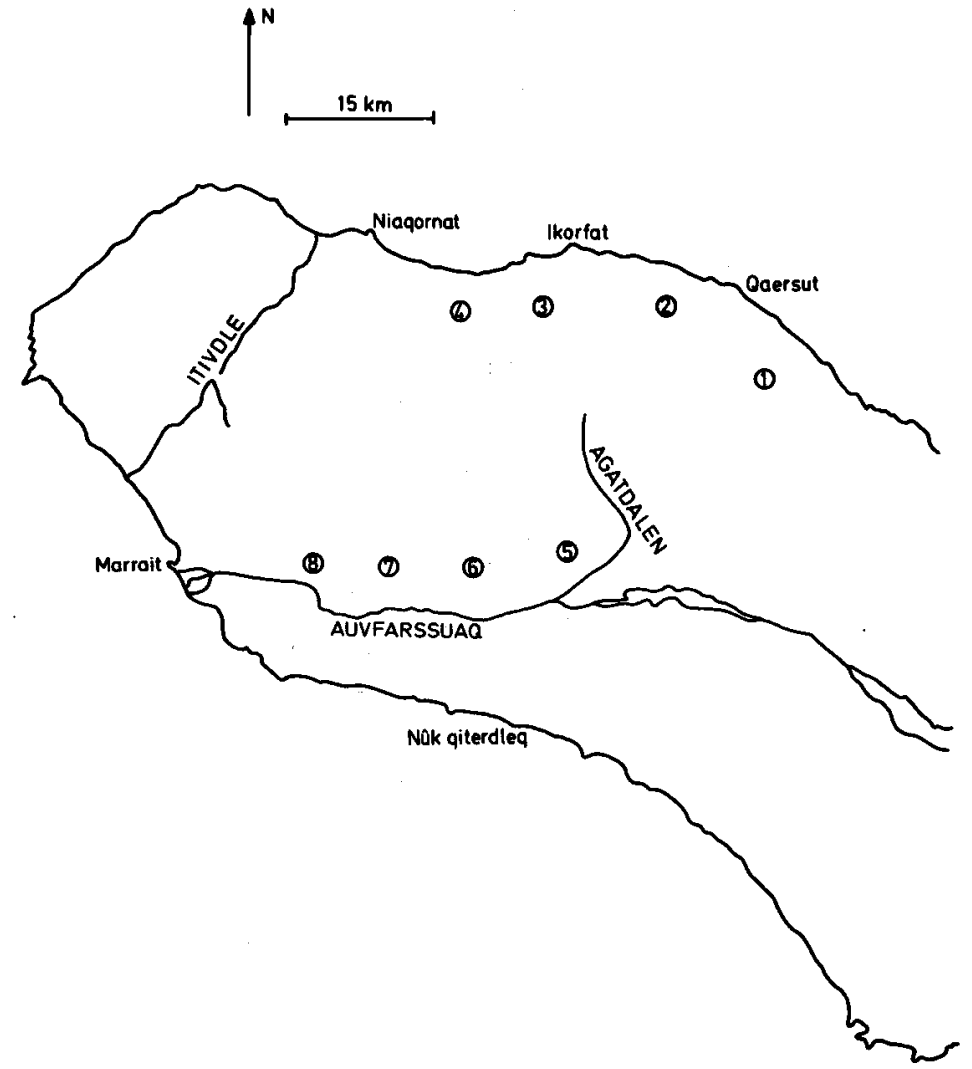

Fig. 1. Sketch map of central and western Nagssuaq. Measured profiles shown by numbers.

Sharma (1975) in a small fault bounded area west of Marrait on Nûgssuaq approximately 15 $\mathrm{km}$ west of profile 8 (Henderson, 1975).

The sequence of basal breccias and normally magnetized lavas in profile 8 is thick compared with the basal breccias of the two eastern profiles in Auvfarssuaq and with the basal breccias in the profiles 2,3 and 4 along the north coast. It is therefore unlikely that the normally magnetized lavas are represented by the subaqueous breccias in central and northern Nûgssuaq. A hiatus which could be correlated with the normally magnetized lavas was not observed in these profiles.

In agreement with Koch (1959) and Pedersen (1973) it is therefore concluded that the volcanic sequence around Marrait and in the outer Auvfarssuaq valley - and also on northern Disko - was already several hundred metres thick when the sediments in central and northern Nûgssuaq were first covered by lavas or pillow breccias. 
Fig. 2. Profile 8 from the north side of the Auvfarssuaq valley $14 \mathrm{~km}$ east of Marrait. The magnetic polarity of the lavas determined on partial demagnetized cores is shown with $\mathbf{N}$ (normally) and $\mathbf{R}$ (reversely). Underlining indicates that the inclination after partial demagnetization is between $51^{\circ}$ and $84^{\circ}$ corresponding to the values found by Athavale \& Sharma (1975) on northern Disko.

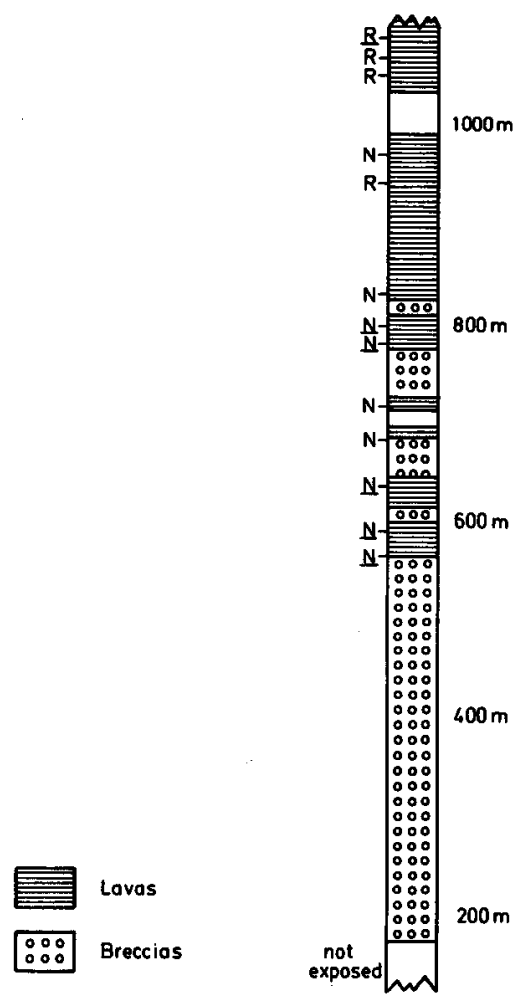

\section{References}

Athavale, R. N. \& Sharma, P. V. 1975: Paleomagnetic results on Early Tertiary lava flows from West Greenland and their bearing on the evolution history of the Baffin Bay - Labrador Sea region. Can. J. Earth Sci. 12, 1-18.

Henderson, G. 1975: Stratigraphy and structure of the Tertiary volcanic rocks of the Marrait kitdlit area, Nûgssuaq. Rapp. Grønlands geol. Unders. 69, 11-16.

Koch, B. E. 1959: Contribution to the stratigraphy of the non-marine Tertiary deposits on the south coast of Nuggssuaq peninsula, northwest Greenland with remarks on the fossil flora. Bull. Grønlands geol. Unders. 22 (also Meddr Grønland 162,1) $100 \mathrm{pp}$.

Kristjansson, L. G. \& Deutsch, E. R. 1973: Magnetic properties of rock samples from the Baffin Bay coast. In Hood, P. J. (edit.) Earth science symposium on offshore eastern Canada. Pap. Geol. Surv. Can. 71-23, 573-598.

Pedersen, A. K. 1973: Report on field work along the north coast of Disko, 1971. Rapp. Grønlands geol. Unders. 53, 21-27. 